\title{
Vagueness in Hoaxes
}

\author{
Nurul Chojimah \\ State Islamic Institute of Tulungagung \\ nurulchoy2@yahoo.com
}

\begin{abstract}
The dominance of the Internet affects all aspects of life, including communication. The ease in spreading information is one of the characteristics of communication in digital era. Passing information is as easy as flicking our fingertips. This ease causes many of us are not careful in comprehending the information. Getting information in social media such as WhatsApp, we speedily pass it to our friends and relatives without questioning the truthfulness of it. In consequence, we frequently pass hoax or fake information. Hoax can be understood as unreal information or fake information. The most prominent characteristic of hoax is vagueness, both linguistic vagueness and source vagueness. The use of deictic expression of time such as today, tomorrow, and yesterdayanddeictic expression of person such as $I$ are the linguistic vagueness commonly occurs in hoaxes. The substantive vagueness is traceable from the absence of sources or references. The advancement of technology and the ease to get information in the digital era should not supersede the truth, which is the value that we must constantly and consistently uphold.
\end{abstract}

Keywords: Hoax, linguistic vagueness, source vagueness

\section{INTRODUCTION}

WhatsApp is mobile messaging which relies on the use of the Internet for the message transmission. It gets more and more popular nowadays, in the sense that its active users keep increasing. It is reported that its monthly active users hit 1.5 billion. WhatsApp confirms that it is the most popular mobile application. The low cost, the simple operation, and the various features pertaining in the application might be the reasons of the popularity.

The other meritof the application is that users can spread contents with ease. Spreading contents and passing information are like flicking our fingertips. It is easy and almost costless. Contents containing videos, images, humors, political issues, advertisements and many others are spreadable with ease and costless. Likewise, pdf files having huge capacity are passable through the WhatsApp. In short, no information is impossible to pass through WhatsApp.

The ease, however, is not without negative impact. It might blunt our sensitivity to the truthfulness of the information. We tend to be not confirmative. Getting contents from friends or relative, we speedily pass it to our friends or relative without evaluating the truthfulness of it. In consequence, hoaxes outbreak everywhere.

In general, hoaxes could be understood as unreal information or fake news. Cambridge Dictionary of American English defines hoax as a plan to deceive a large group of people [1]. The World Book Dictionary defines hoax as made-up story passed off true [2].The main characteristic of hoaxes is vagueness which can be classified into linguistic and substantive vagueness.

\section{LINGUISTIC VAGUENESS}

Linguistic vaguneness is the vagueness due to linguistic factors such as dictions, the use of adverbs, the use of pronouns, and others. The use of deictic expressions of time is one example of linguistic vagueness commonly pops up in hoaxes. Deictic expression of time is time signals whose referents are relative, depending on when the utterance is stated [3]. Today, tomorrow, yesterday are a few examples of deictic expressions of time. The meaning of those adverbial of time are respectively on this day, the day after today, and the day before today. The referents of those adverbs vary, depending on when the utterance is stated. The intended day of the adverb tomorrow in 'see me tomorrow'is Friday if the utterance is stated on Thursday, but when it is stated on Friday, the intended day is Saturday. On the basis of this, it can bestated that an invitation or an appeal using such vague time signals needs further confirmation.

Deictic expressions of person is the other indication of linguistic vagueness. Levinson, in his further explanation mentions that first person pronoun(I or saya) and second person pronouns(you or kamu) are deictic expressions of person [3]. They are deictic because the referents of those pronouns are dependent on the role of interactants in communication. Consider a short dialogue that follows:

$\mathrm{X} \quad$ : I need to send an e-mail to the committee. Have you?

$\mathrm{Y} \quad$ : I did it yesterday.

In the dialogue, the referents of $I$ and you change as the role of the communicants changes. When $\mathrm{Y}$ is the addressee, she/he is the referent of you. Y, however, automatically shifts into $I$ when she/he is the addresser. It suggests that in order to determine the referent of $I$ and you, we need to know the context, in the sense that we need to determine who the addresser and addressee are.

Halliday mentions that context as the events that are going around when people speak or write [4]. In line with this, Celce-Murcia et al. explain that human communication relies much on context and the shared knowledge that the interactants have [3].

Using this knowledge at hand, WhatsApp users should not directly believe with appeals or news passed by others if they contain vague time signals and vague addresser. Consider messages that follow, all of which are the ones shared by my friends through WA.

...saya dapat pesan WA dari Prof. DR. H. Suparman Usman (Dosen, Guru Besar IAIN SMHB Serang \& Untirta Serang) berikut ini: hari ini dan besuk jangan access Google dan Youtube karena...

English Version

...I got a WhatsApp message from Prof. DR. H. Suparman Usman (Lecturer, Professor at IAIN SMHB Serang \& Untirta Serang) as follows:do not get the access to Google and Youtube today and tomorrow because... 


\author{
Original version \\ maka... \\ ...mulai hari ini WhatsApp sudah diakuisisi oleh Google, \\ English Version \\ ...starting from today on, WhatsApp has been
}

The addressee of (1) and (2) are the readers or WhatsApp users. The addresser of those messages are the writers. To which person does the pronoun saya or $I$ in (1)? Answering this question properly, we need to know who the writer of the message is. Unfortunately, message (1) does not mention any name. In consequence, readers get perplexed when they are required to determine who the referent of the pronoun saya or I.

To what days do the adverbs of time todayand tomorrowin (1) refer? The referents of them are relative, depending on when the messages are stated. When the message is written and read on Tuesday, the referents of (1) are respectively Tuesday and Wednesday. It means that the readers of (1) are requested not to open Google Youtube on Tuesday and Wednesday. The intended days on (1), however, might get different if the messages are stated and read on a day other than Tuesday.

Some notes are relevant for such contents. Message (1) is a request, and in consequence it sets future actions. Ideally, a request setting future actions provides with clear and concise information, including the particular date and time or the schedule of the action. The clarity and conciseness of the schedule prevent the requestee from the perplexity. Furthermore, in order to be trustworthy, the request must be provided with the complete name of the requester and his/her contact number or address. Mentioning the first person pronoun saya without any referent suggests that the writer of the message might be a random person. It might be anyone. As such, no one is responsible for the content of the message.

The task of message (2) is to inform an important event: the acquisition of WhatsApp by Google. Acquisition is a corporate action in which one company buys some or all of shares of other company. The day on which the letter of the acquisition is signed is a historic day for both companies. The day is the starting point for them to set new hopes, new visions, new strategies, and new actions. Considering the importance of the date, mentioning the date explicitlyis a necessity, otherwise the truthfulness of the event cannot be verified. As such, the date must be well recorded.

Relying on the analysis, messages (1) and (2) are vague, and they need further clarification. On the basis of the crucial function of date in such messages, it can be concluded that messages (1) and (2) are fake news or hoaxes. In line with this, Harley mentions that one of the characteristics of hoaxes and chain letters is that they are usually undated, or have no realistic or verifiable date [5]. In short, the truthfulness of messages is traceable from its linguistic clarity, one of which is the use of verifiable date.

\section{SOURCE VAGUENESS}

In addition to linguistic vagueness, hoaxes are identifiable from its unverifiable sources. The prominent characteristic of trustworthy information is that it can be verified. It means that any information pertaining in it can be confirmed that it is true. One of the characteristics of verifiable information is the existence of sources such as the name of persons, authors of books, titles of books, and website addresses. Consider the message (3) that follows:

Original Version

Penerbangan Garuda Indonsia memberikan tiket gratis 2 untuk semua orang, untuk merayakan ulang tahun mereka, klik di sini untuk mendapatkan Anda: http://www.garudaindonesia.com/tickets.

English Version

Garuda Indonesia Airways would like to give away two tickets for free for those celebrating their birthday, click here to get them: http:www.garuda-indonesia.com/tickets.

Message (3) contains substantive vagueness since the web address mentioned in it cannot be verified. In its official release, the flight company confirmed that any information concerning tickets could be confirmed through their official website, instead of the one stated in (3). As such, all information stated in the web can be confirmed that it is not true. It means that two free tickets are not factual.

\section{WHY DOES VAGUENESS OCCUR?}

Social media, including WhatsApp is a public writing area. In it, everybody could easily become a writer and messenger. We could write anything coming up in our mindpersonal stories, humors, religious and political issueswithout any filter. What we write in our social media account does not undergo a long and strict process dealing with its language nor its content. Any language style we use is acceptable, and any content we share is publishable. Filtering process by experts and proof readers is no longer called for. As such, the path to make our ideas publishable seems very smooth; it is not as meticulous as it used to be. In short, anybody could be a writer.

The ease in publishing our writing described above, however, is not without impact. The smooth path to reach the label of 'writer' blunts our sensitivity. We are not sensitive to the quality of the writing we read. We are rarely critical of the presence unverifiable schedules and sources. Confirmng the truthfulness of the content is not our concern. In consequence, we tend to accept the idea behind the writing as the truth. As such, we speedily share it to others. The implication is that social media is filled with questionable-quality writings.

The ease in publishing and passing the writing described above might explain why invitations and appeals with unverifiable schedules (data 1\&2) and information without any trusted sources (data 3 ) could easily fill social media. In the long run, such condition is harmful, in particular for those who have not good reading habit yet. Being flooded with information, people find it difficult to distinguish between the truth and lie. In consequence, they tend to accept it as the truth. Thus, one of the factors contributing to the occurence of 
vagueness in most contents we read is our minimum sensitivity to the truthfulness of the content.

\section{CONCLUSION}

Being encountered with the massive circulation of hoaxes whose characteristics are described earlier, WhatsApp users are demanded to be linguistically and substatively sensitive. The former sensitivity deals with the use of deictic expressions. It means that whenever they get undated requests, appeals, or information, they do not need to take it into account. Likewise, they do not need to take it deeply whenever they get messages using unverifiable addresser. The later sensitivity is concerned with the content of the message in general. As they perceive that the message is vague and does not make sense, they do not need to keep it.

\section{REFERENCES}

[1] Cambridge Dictionary of American English. Cambridge. Cambridge University Press. (2000)

[2] The World Book Dictionary. World Book Inc. (1995)

[3] C. S. Levinson. Pragmatics. Cambridge. Cambridge University Press.

[4] Marianne, Celce-Murcia,.\& Olshtain, Elite. Discourse and Context in Language Teaching. Cambridge. Cambridge University Press. (2000)

[5] D. Harley, "Common Hoaxes and Chain Letters.” 2008

[6] M. A. K. Halliday, The Notion of 'context' in language education . In T. Le \& M. McCausland (Eds), "Language Education: International Developments" (pp. 4-26). Proceedings of the international conference, Ho Chi Minh Vietnam 